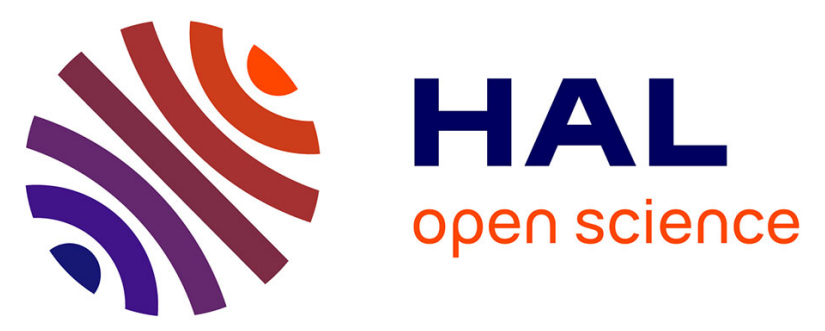

\title{
Regulation of MMP/TIMP balance as therapeutic target in pulmonary diseases
}

Corinne Martin-Chouly, S. Guillot, Stéphane Jouneau, Sylvie

Caulet-Maugendre, Laurent Vernhet, Vincent Lagente, Philippe Delaval

\section{To cite this version:}

Corinne Martin-Chouly, S. Guillot, Stéphane Jouneau, Sylvie Caulet-Maugendre, Laurent Vernhet, et al.. Regulation of MMP/TIMP balance as therapeutic target in pulmonary diseases. Letters in Drug Design and Discovery, 2006, 3 (3), pp.159-171. 10.2174/157018006776287005 . hal-00699583

\section{HAL Id: hal-00699583 https://hal.science/hal-00699583}

Submitted on 16 Nov 2021

HAL is a multi-disciplinary open access archive for the deposit and dissemination of scientific research documents, whether they are published or not. The documents may come from teaching and research institutions in France or abroad, or from public or private research centers.
L'archive ouverte pluridisciplinaire HAL, est destinée au dépôt et à la diffusion de documents scientifiques de niveau recherche, publiés ou non, émanant des établissements d'enseignement et de recherche français ou étrangers, des laboratoires publics ou privés.

\section{(ㅇ)(1) $\$$}

Distributed under a Creative Commons Attribution - NonCommercial| 4.0 International 


\title{
Regulation of MMP/TIMP Balance as Therapeutic Target in Pulmonary Diseases
}

\author{
Corinne A.E. Martin-Chouly*,1, Stéphanie Guillot ${ }^{1,2}$, Stéphane Jouneau ${ }^{1,3}$, Sylvie Caulet- \\ Maugendre ${ }^{1,4}$, Laurent Vernhet ${ }^{1}$, Vincent Lagente $^{1}$ and Philippe Delaval ${ }^{1,3}$
}

${ }^{1}$ INSERM U620, Faculté des Sciences Biologiques et Pharmaceutiques, Université de Rennes 1, Rennes, France

${ }^{2}$ Service de Physiologie, CHU de Rennes, Hôpital Pontchaillou, Rennes, France

${ }^{3}$ Service de Pneumologie, CHU de Rennes, Hôpital Ponchaillou, Rennes, France

${ }^{4}$ Service d'anatomopathologie, CHU de Rennes, Hôpital Ponchaillou, Rennes, France

\begin{abstract}
Matrix metalloproteinases (MMPs) are a family of zinc endopeptidases, regulated by endogenous tissue inhibitors (TIMPs) and inducer (EMMPRIN). The demonstration of a functional role of MMPs in pulmonary diseases raises the possibility of therapeutic intervention targeting MMP/TIMP balance to prevent pathological processes.
\end{abstract}

Keywords: Pulmonary diseases, MMP, TIMP, EMMPRIN, regulation.

\section{INTRODUCTION}

Tissue remodelling usually involves two distinct processes: physiological remodelling or regeneration, with the replacement of injured tissue by parenchymal cells of the same type, and pathological remodelling, which lead to altered restitution of airway structure. Remodelling of lung architecture is a hallmark of many lung diseases, such as loss of alveolar walls in emphysema, subepithelial fibrosis in asthmatics airways, intra-alveolar fibrosis in idiopathic pulmonary fibrosis (IPF), cavity formation in tuberculosis, and bronchiectasis in cystic fibrosis. Furthermore in lung cancer, increased matrix turnover is thought to promote tumour cell invasion. Despite advances in our understanding of their pathogenesis, the currently recommended treatments have limited clinical efficacy in most of lung disorders, and patients often progress to severe respiratory failure and death. All of the pathologic changes involve extensive modifications of lung extracellular matrix (ECM). The interaction of cells with ECM is critical for the normal development and function of organisms. Modulation of cellmatrix interactions occurs through the action of unique proteolytic systems responsible for hydrolysis of a variety of ECM components. By regulating the integrity and the composition of the ECM structure, these enzyme systems play a pivotal role in the control of signals elicited by matrix molecules. The turnover and remodelling of ECM must be highly regulated since uncontrolled proteolysis contribute to abnormal development and to the generation of many pathological conditions characterised by excessive degradation or synthesis of ECM components [1]. Matrix metalloproteinase (MMPs) are a major group of enzymes that regulate ECM composition. MMPs have been proposed to be key enzymes in causing these changes because of their capacity to cleave structural proteins such as collagen,

*Address correspondence to this author at the INSERM U620, Université de Rennes 1, 2 avenue du Pr. Léon Bernard, 35043 Rennes cedex, France; Tel: 33 (0) 223323 49 04; Fax: 33 (0) 22232347 94; E-mail: corinne.chouly@univ-rennes1.fr elastin, fibronectin and laminin. Although increased expression of MMPs occurs in response to a particular need in a normal biological process, an abnormal regulation of their expression induce the development of several lung diseases. Based on this evidence, the pharmaceutical industry produced several tolerated, orally active MMP inhibitors. Phase III clinical trials initiated in 1997-98 using marimastat (BB-2516), prinomastat (AG3340), tanomastat (BAY 12-9566) and neovastat (BMS-275291) alone or in combination with standard chemotherapy in patients with advance lung cancer have recently been reported [2]. Although no clinical efficacy was clearly demonstrated with MMP inhibitors, this review tries to discuss the therapeutical interest of MMPs/TIMPs balance modulation.

\section{MMPs: STRUCTURES, CELLULAR SOURCES, FUNCTIONS}

Metalloproteinases (MMPs), an important family of metal-dependent endopeptidases, are responsible for the degradation of extracellular matrix components. All members of this family have a zinc and a calcium binding catalytic domain, so that they depend on these ions for their activity. Presently, MMPs identified share several common features: signal peptides, prodomain, and catalytic domain. These enzymes are secreted by various human cells as inactive proenzyme (zymogens) and are thought to be activated in the tissue by proteolytic cleavage of the propeptide [1]. The MMP family contains at least 28 known members, which are grouped according to their substrate, location, and structure specificities (Table 1). The collagenases (MMP-1, -8, -13) degrade fibrillar forms of interstitial collagen. The gelatinases (MMP-2 and -9) are specific for gelatin and denatured collagens of the basement membrane. Stromelysins (MMP-3, -10, -11) cleave noncollagen components such as fibronectin, laminin, and vitronectin. Metalloelastase (MMP-12) cleaves elastin, and membrane type (MT)-MMP (i.e. MMP-14) cleaves various collagens and noncollagen components [3, 4]. MMPs are 
Table 1. Matrix Metalloproteinases and the Arrangement of their Domain Structure. The First Side, Starting from the NTerminus Domain, is the Signal Peptide. The Propeptide Region Contains the 'Cysteine Switch' Sequence whose Cystein Residue Coordinates to the Catalytic $\mathrm{Zn}^{2+}$ Ion in the Proenzyme. The C-Terminus of Transmembrane MMPs is Intracellular

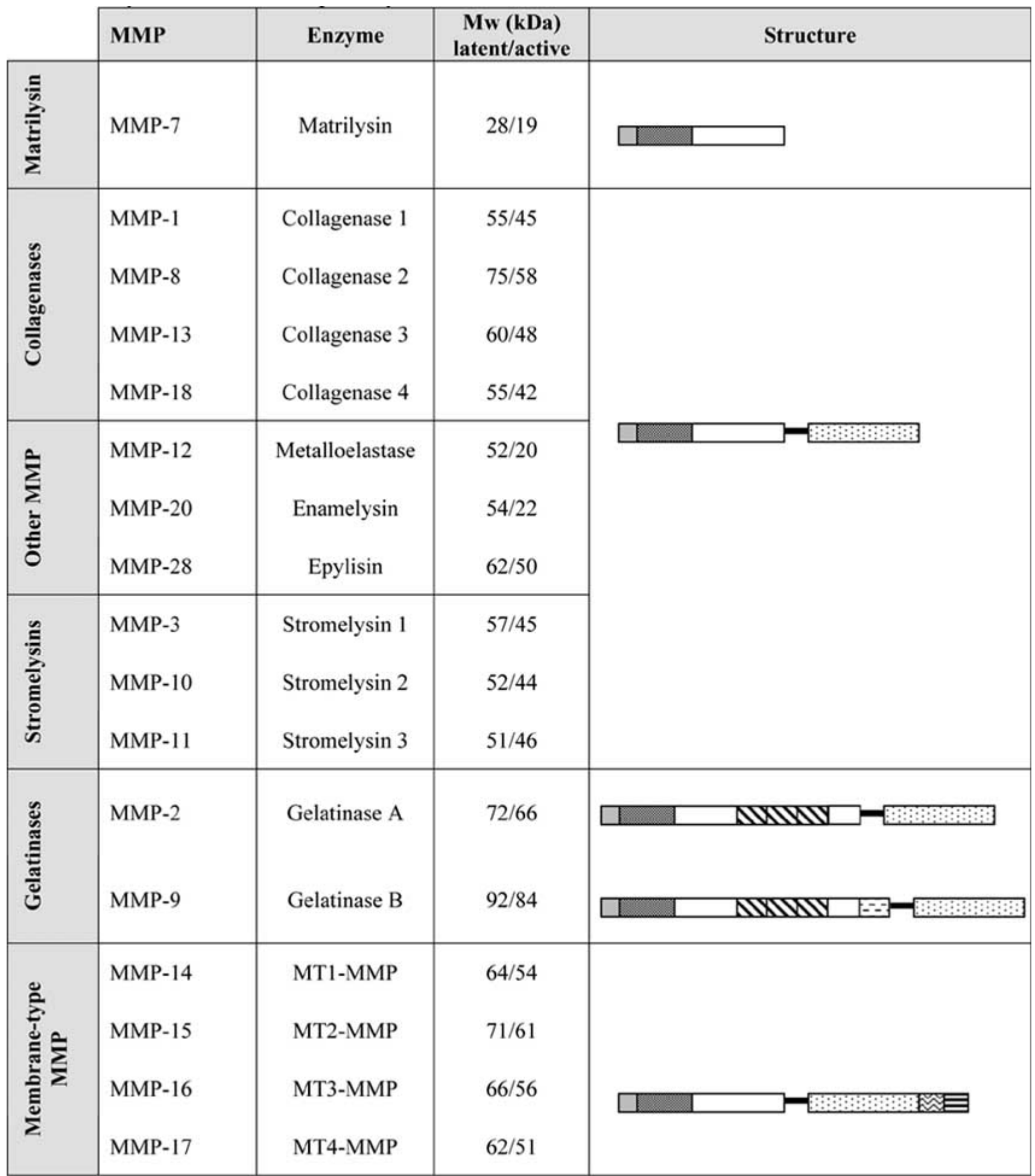

$\square$ signal peptide, $\square$ propeptide, $\square$ catalytic domain, $\mathbf{Q}$ fibronectin type II domain, $\boldsymbol{\square}$ linker

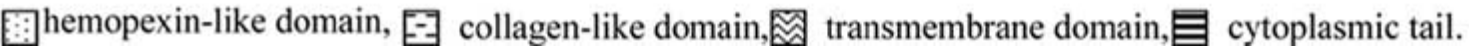


synthetised and secreted in the extracellular space as a proenzyme where the active site of the protein is inactived through interaction between $\mathrm{Zn}^{2+}$ ion, sequestrated by histidines on the catalytic domain and a cysteine residue on the prodomain fragment. Disruption of the cysteine-zinc bond by conformational change or limited proteolysis leads to the opening of the switch. Then the autocatalytic cleavage of the propeptide yields the active enzyme. The activation of MMPs may also occur through the cleavage by MT-MMPs [5]. For example, the cleavage of proMMP-2 by MT1-MMP generates an active form of MMP-2 which is then released into the extracellular space. Furthermore, free radicals mostly generated during inflammatory processes, could activate MMP-2 through oxidation reaction [6].

Although the healthy adult lung is not a major source of MMPs, inflammatory and parenchymal cells such as alveolar macrophage, airway epithelium, fibroblast, and smooth muscle have the capacity to express active MMPs following stimulation by a variety of agents such as infectious pathogens, environmental toxins, growth factors and cytokines which either induce (IL-1, TNF- $\alpha$, TGF- $\alpha$, EGF, FGF and PDGF) or repress (TGF- $\beta$, IL-10 and IL-4) transcription of MMP genes [7-9]. This suggests that chronic inflammation causes injury to the airways and modulates fibrogenesis and parenchymal destruction. In response to an inflammatory stimulus, alveolar macrophages rapidly release the following: 1) cytokines and chemokines such as IL-8, TNF- $\alpha$, CCL-18 and MIP-1, which act in further recruiting polymorphonuclears that can, in turn, release more inflammatory mediators; 2) leukotriene $B_{4}$ $\left(\mathrm{LTB}_{4}\right)$, a potent chemoattractant for other inflammatory cells; 3 ) reactive oxygen intermediates, which can contribute towards enhancing the inflammatory response; and 4) MMPs, which were induce in various cells through numerous intracellular signalling systems involving tyrosine kinase and MAP-kinase, and can degrade the interstitial matrix. However, whether suppressing airway inflammation effectively prevents or reverses airway structural changes is controversial. Indeed, unlike several MMPs expressed or released only in response to injury, disease, or inflammation, MMP-2 and MMP-7 (matrilysin) are expressed by noninjured, noninflamed fibroblast and epithelium respectively, in most, if not all, adult tissues. In adult human lung, whether normal or diseased, matrilysin is expressed by epithelial cells lining peribronchial glands and conducting airways [10]. The expression of MMP-2 and MMP-7 in noninjured, normal cells demonstrates that these enzymes serve a common homeostatic function. Conversely, inflammatory and parenchymal cells also contribute to the resolution of the inflammatory response because they are able of releasing several anti-inflammatory molecules, such as TGF- $ß$, IL-10 and tissue inhibitors of MMPs (TIMPs).

Because of the potent bioactivity of MMPs and the potential risk for tissue damage, the MMPs' activity is tightly regulated. Extracellular matrix metalloproteinase inducer (EMMPRIN) is a transmembrane glycoprotein member of the immunoglobulin superfamily [11]. EMMPRIN is also known as CD147, HAb18G and M6 in man, basigin and gp42 in mouse, OX-47 and CE9 in rat, and HT7, neurothelin and 5A11 in chicken [12, 13]. EMMPRIN was originally isolated from the LX-1 human pulmonary carcinoma cell line and termed tumour cell- derived collagenase stimulatory factor (TCSF) because it stimulated stromal matrix metalloproteinases production and facilitated the migration of neoplastic cells through the extracellular matrix, suggesting an important role in tumour progression [11, 14-16]. EMMPRIN is present in many human tissues including lung, breast, skin, eye, and heart in physiological and pathological conditions [15, 17-21]. Indeed, EMMPRIN is detected in bronchoalveolar lavage (BAL) fluids from normal rats and mice [22, 23] and in bronchiolar epithelial cells of normal mice [22]. Moreover, the expression of EMMPRIN in BAL fluids and lung tissue is markedly increased in diverse lung pathologic processes including ventilator-induced lung injury in rats [23] and bleomycin-induced lung fibrosis in mice [22]. In these pathologic conditions, airways epithelial cells and alveolar macrophages appeared to be the cellular sources of EMMPRIN. EMMPRIN is also detected in BAL fluids from healthy subjects and in normal human bronchial cells $[17,24]$. The increase of EMMPRIN production in smoker's BAL fluids has been highlighted and its expression was observed in alveolar macrophages, bronchial glands and bronchiolar epithelial cells from smoker's lung [24]. Furthermore, several studies have showed a high expression of EMMPRIN in all malignant and stromal cells from lung cancers and pleural mesotheliomas [17, 18, 25]. However, the mechanisms by which EMMPRIN induces MMP production have not been fully established. Nevertheless, EMMPRIN has been shown to stimulate mesenchymal cell production of MMP-1 (collagenase-1), MMP-2 (gelatinase A), MMP-3 (stromelysin-1), MMP-9 (gelatinase B) and MT1-MMP (MMP-14) which is activator of proMMP-2 [14, 17, 26-30].

Indeed several active MMPs are able to activate other proMMPs, indicating positive feedback mechanisms. On top of activation of proMMP-2 by MT1-MMP, it was also shown, for instance, that MMP-3 can activate pro-MMP-9 [31], and MMP-3 and -10 can superactivate procollagenase, generating collagenase with higher specific activity [32, 33]. Moreover, multiple enzymes from different families may cooperate in tissue remodelling at the same time and place. For example, metalloelastase, as well as other MMPs, degrades $\alpha_{1}$-antiproteinase inhibitor, and neutrophil elastase, a serine proteinase, degrades TIMPs. These enzymes, by neutralizing each other's natural inhibitors, can thus amplify overall proteolytic activity. This concept was shown in vivo in studies by Liu et al. [34]. A role for MMP-9 in emphysema was not clearly demonstrated. However, metalloelastase (MMP-12) degrades $\alpha_{1}$-antiproteinase inhibitor, in part explaining why metalloelastase deficient mice are totally protected from smoke-induced emphysema, whereas neutrophil elastase deficient mice are only partially protected [35].

Damaged alveoli during inflammatory lung diseases can be repaired by replacement of injured alveolar cells, restoration of damaged ECM, and clearance of plasma proteins that have leaked into the alveolar space. Plasmin plays an important role in this repair process by being involved in cell migration, modulation of inflammatory activity, and breakdown of fibrin and other ECM. This latter function of plasmin may be important for limiting scar formation by dissolving the provisional matrix on which fibroblasts invade and secrete interstitial collagens. During 
many acute and chronic inflammatory lung disorders, fibrin accumulates in lung tissue. The fibrinolytic activity is decreased in BALF from patients with the adult respiratory distress syndrome [36], idiopathic pulmonary fibrosis [37], sarcoidosis [37, 38], and bronchopulmonary dysplasia [39]. All of the above diseases have been associated with the development of pulmonary fibrosis. In vitro, plasmin directly activates pro-MMP-1, -3, -9, -10, and -13 [40], whereas proMMP-2 is indirectly activated by plasmin [41].

MMPs are restrained by their natural inhibitors known as tissue inhibitors of matrix metalloproteinases (TIMP) which are present on the extracellular compartment. Four family members of TIMPs have been characterised so far, designated as TIMP-1, TIMP-2, TIMP-3, and TIMP-4. TIMP-1 and TIMP-2 are capable of inhibiting the activities of all known MMPs (except for TIMP-1, which failed to inhibit MT1-MMP) and as such play a key role in maintaining the balance between extracellular matrix (ECM) deposition and degradation in different physiological processes. However, there are differences in the affinity for specific MMPs (e.g. TIMP-3 is a more potent inhibitor of MMP-9 than other MMPs).

The reversion-inducing gene named RECK (reversioninducing-cysteine-rich protein with Kazal motifs) is unique in that it encodes an extracellular protein with protease inhibitor-like domains and its expression is suppressed strongly in many tumours and cells transformed by various kinds of oncogenes. RECK is a membrane-anchored glycoprotein of approximately $110 \mathrm{kDa}$ that contains multiple epidermal growth factor (EGF)-like repeats and serine protease inhibitor-like domains [42], but has no structural homology with TIMPs. The RECK gene is widely expressed in many normal organs, including the lung, and the expression is low or undetectable in many tumourderived cell lines. The RECK-encoded protein acts as a membrane-anchored regulator of matrix metalloproteinases (MMPs), including MMP-2, MMP-9, and MT1-MMP. Previous experimental studies revealed that RECK can inhibit tumour invasion and metastasis. [42-44]. These experimental data have suggested a potential importance of RECK in the diagnosis and therapy of malignant tumours. Nevertheless, only a few studies have demonstrated that RECK expression at the mRNA or protein level can be a useful prognostic indicator in cancer patients with hepatocellular carcinoma [45], breast cancer [46], pancreatic cancer [47] and non-small cell lung cancer [48]. RECK negatively regulates MMP-9 in two ways: suppression of MMP-9 secretion from the cells and direct inhibition of its enzymatic activity. These findings suggest that RECK may serve as a negative regulator for MMP-9 in normal cells, and its down-regulation by oncogenic signals therefore would facilitate tumour invasion and metastasis. Hypothetically, the efficacy of nonsteroidal anti-inflammatory drugs (NSAIDs) as antimetastatic and antiangiogenic drugs might be mediated by their induction of RECK expression as described in lung cancer.

\section{MMPs/TIMPs BALANCE IN LUNG PATHOLO- GICAL PROCESSES}

Genetic studies in both mice and men have provided insights into the role of MMPs in lung diseases. There are numerous examples of MMP-null mice that have defective remodelling and repair responses to pathological lung situations. Hautamaki et al. [49] showed that smokeaddicted metalloelastase-MMP-12 knockout mice developed emphysema less readily than wild-type mice. MMPs $-2,-7$, -9 and -11 have all been shown to contribute to tumour progression in studies using MMP-deficient mice [50]. The association of matrix proteolysis and cancer has also long been recognised, and destruction of the basement membrane is a well-established hallmark of malignancy [51].

\section{Chronic Obstructive Diseases}

Asthma, chronic obstructive pulmonary disease (COPD) and emphysema are diseases associated with an inflammation of the airways and lung parenchyma. During the course of asthma, MMP-2, $-8,-9$ and TIMP-1 are expressed at baseline and the allergen exposure or exacerbations of the disease lead to an increase of MMP-9 secretion being at this time much higher than that of TIMP1, allowing a temporarily ECM damage, possibly followed by abnormal repair. Animal models suggest a predominant role for MMP-9 and MMP-12 in the pathogenesis of pulmonary inflammation and link an absence of MMP-2 to an increased parenchymal inflammation. It has become clear that the inflammatory process increases in intensity as COPD progresses and there is a complex remodelling process in the peripheral lung, resulting in parenchymal destruction (emphysema) and fibrosis of small airways (chronic obstructive bronchiolitis) [52]. In COPD and emphysema, human studies indicate an over-secretion of MMP-2, -8, -9 and animal models point out MMP-1 and MMP-12 as being key players in the pathogenesis of emphysema [53]. Studies in COPD have reported an abnormal release of IL-8, MMP-1 and MMP-9 by alveolar macrophages in these patients. Alveolar macrophages harvested from patients with COPD release more proinflammatory mediators $\left(\mathrm{LTB}_{4}, \mathrm{IL}-8\right)$ and/or less antiinflammatory molecules (TGF- $\beta_{1}$, TIMP-1) than those obtained from smokers with preserved lung function [54, 55]. Taken together, these data identify specific MMP inhibition as appropriate target for therapeutic intervention in asthma or COPD/emphysema. Regarding EMMPRIN expression in lung of smokers, Betsuyaku et al. [24] have observed that EMMPRIN levels were significantly elevated in smokers' BAL fluid compared with BAL fluid from non smoker subjects, but without differences between smokers with or without emphysema.

\section{Pulmonary Fibrosis}

Pulmonary fibrosis is a common response to various injuries to the lung and is characterised by structural changes in the lung parenchyma. An injury to alveolar epithelium appears to be necessary for this lesion to progress to fibrosis. Thereafter, changes include increase in lung matrix and alterations in the numbers and spatial relationships of lung parenchymal cells, mainly the proliferation and activation of fibroblasts and myofibroblasts. Thickening of the alveolar wall can result to matrix deposition within the interstitium and as a result of "mural incorporation" of organised airspace exudates [56]. The fibroproliferative process involves the participation of a variety of cytokines and inflammatory mediators, among MMPs and their specific inhibitors, by 
resident and inflammatory cells. Lung tissue and BAL fluids from individuals with pulmonary fibrosis contain high levels of MMP-1, derived from alveolar macrophages and epithelial cells, MMP-2, localised in myofibroblasts, and MMP-9, derived from macrophages and neutrophils [57, 58]. On the other hand, the ECM can be degraded, and it is likely that the fibrogenic process may also result from a deficit in ECM degradation. However, the relationship between ECM degradation and fibrogenesis is more complex than initially suspected because abnormal ECM accumulation is often preceded or combined with an increased expression of ECM-degrading enzymes. This increased proteolytic activity is presumably required for degradation of the normal ECM by infiltrating inflammatory and fibroblastic cells and its replacement by abnormal ECM. However, TIMP-1 was found in interstitial macrophages and TIMP-2 in fibroblast foci [59]. TIMP-2 increased in BAL fluids from IPF patients may contribute to the stable ECM deposition [26, 59]. EMMPRIN was expressed in experimental bleomycin-induced lung fibrosis in mice, and cellular sources of EMMPRIN was identified as airways epithelial cells and alveolar macrophages [22].

\section{Bronchopulmonary Carcinomas}

Lung carcinoma is a common and very aggressive neoplasm including histologically different entities with unfavourable prognosis. The association of matrix proteolysis and cancer has also long been recognised, and destruction of the basement membrane is a well-established hallmark of malignancy $[51,60,61]$. The number of studies suggesting that MMPs may be involved in lung cancer progression is increasing. Bronchopulmonary carcinomas commonly overexpress the mRNA for MMP-1, -2, -9, -11, MT1-MMP and TIMP-1 to -4 , especially when presenting with a malignant phenotype and high tumour stage $[62,63]$. In animal models, MMPs $-2,-7,-9$ and -11 have all been shown to contribute to tumour progression in studies using MMP-deficient mice [50]. The MMP-2 and -9 have been associated with increased tumour spread and poor prognosis in lung cancer $[64,65]$. Several studies have presented an association between the prognosis and the expression of MMP-2 or -9 in the primary tumour in different types of lung carcinoma. Correlation with survival has been reported in lung adenocarcinoma [65]. In non-small cell lung carcinoma (NSCLC), the mRNA for MMP-2, -9 and ecadherin can predict the prognosis [63, 66]. Cox et al. [67] have found MMP-9 immunoreactive protein to be a marker of poor outcome in operable NSCLC. The study of Sienel et al. [68] further confirmed the role of MMP-9 as a marker for aggressive behaviour when immunohistochemically homogeneous MMP-9 expression was found to correlate with compromised cancer-related survival in NSCLC. In a recent study of Aljada et al. [69], the immunoreactive protein of TIMP-1 in primary tumours representing NSCLC also correlated with adverse outcome. Patients presenting with a TIMP-1 positive neoplasia were found to have a high $(90 \%)$ risk of death according to multivariate analyses. It is possible that the MMP status might be worth determining also from blood samples in lung cancer patients. Plasma or serum MMP-9 and serum TIMP-1 levels have both been shown to be prognostic for poor survival in lung carcinoma patients [70]. The tumorigenic potential of EMMPRIN, also named tumour cell-derived collagenase stimulatory factor (TCSF), is not enough to demonstrate in several cancers, including bronchopulmonary carcinomas [16, 20]. Polette et al. [18] related a higher expression of EMMPRIN mRNA in human lung cancers than in normal tissues, suggesting that EMMPRIN was an important factor in cancer progression. It was strongly expressed in all malignant human epithelial cells and was also found in some stroma cells from lung carcinomas close to tumour cells stimulating production of MMPs by these cells [17, 30]. EMMPRIN has also been found with a strong immunoreactivity in pleural mesotheliomas [25]. These studies so far suggest that the use of gelatinases, their inhibitors and/or EMMPRIN, as markers of matrix degradation and therapeutical target could be promising in assessing prognosis and therapy in lung cancer patients.

\section{THERAPEUTIC STRATEGIES FOR MODULA- TION OF MMP/TIMP BALANCE}

Because MMPs play a role in tissue destruction in numerous lung diseases, such as COPD, asthma and cancer, there is tremendous development in therapeutic strategies that block MMP activity. Indeed we have to consider different processes contributing to decrease MMP activity: inhibition of EMMPRIN, plasmin, cytokines and/or growth factors, but also stimulation of TIMP and/or RECK. However, some other pulmonary pathologies result from an excess of normal components of ECM, such as lung fibrosis. These lead to consider therapeutic strategies that inhibit TIMP, RECK and/or EMMPRIN. The activity/production of MMPs should be regulated at two points - enzyme activation/inactivation and gene expression - and is further controlled by substrate availability and affinities (Fig. 1).

Although the TIMPs were considered as potential therapeutics for diseases in which exuberant MMP activity was implicated, they were rapidly surpassed by smallmolecule inhibitors. Several approaches were taken. Pseudopeptides that mimic MMP substrates and nonpeptidic molecules that bind the catalytic zinc were designed, using important insights that were gained from structural studies or by combinatorial chemistry. Original compounds focused primarily on a hydroxamate moiety as the zinc-binding group, but intense competition soon resulted in a repertoire of compounds, which contained various functional groups that were optimised for potency, selectivity and bioavailability.

\section{Activation/Inactivation of MMP}

\section{Common Chelators}

MMPs are generally inhibited by compounds containing reactive zinc-chelating groups, such as thiol or hydroxamate. MMP should be blocked by the $\mathrm{Mg}^{2+} / \mathrm{Ca}^{2+}$ chelator EDTA, the $-\mathrm{SH}$ group of cysteine or captopril, an inhibitor of angiotensin converting enzyme, which coordinate to the zinc atom. Several enzymes involved in the metabolism of extracellular matrix components, such as MMP, were also shown to be inhibited by excess $(>5 \mu \mathrm{M})$ metal ions [71]. It is believed that metal ions, such as $\mathrm{Zn}^{2+}, \mathrm{Cd}^{2+}$ and $\mathrm{Cu}^{2+}$, interact with amino acid residues causing conformational changes that inactivate the catalytic function of MMPs. 


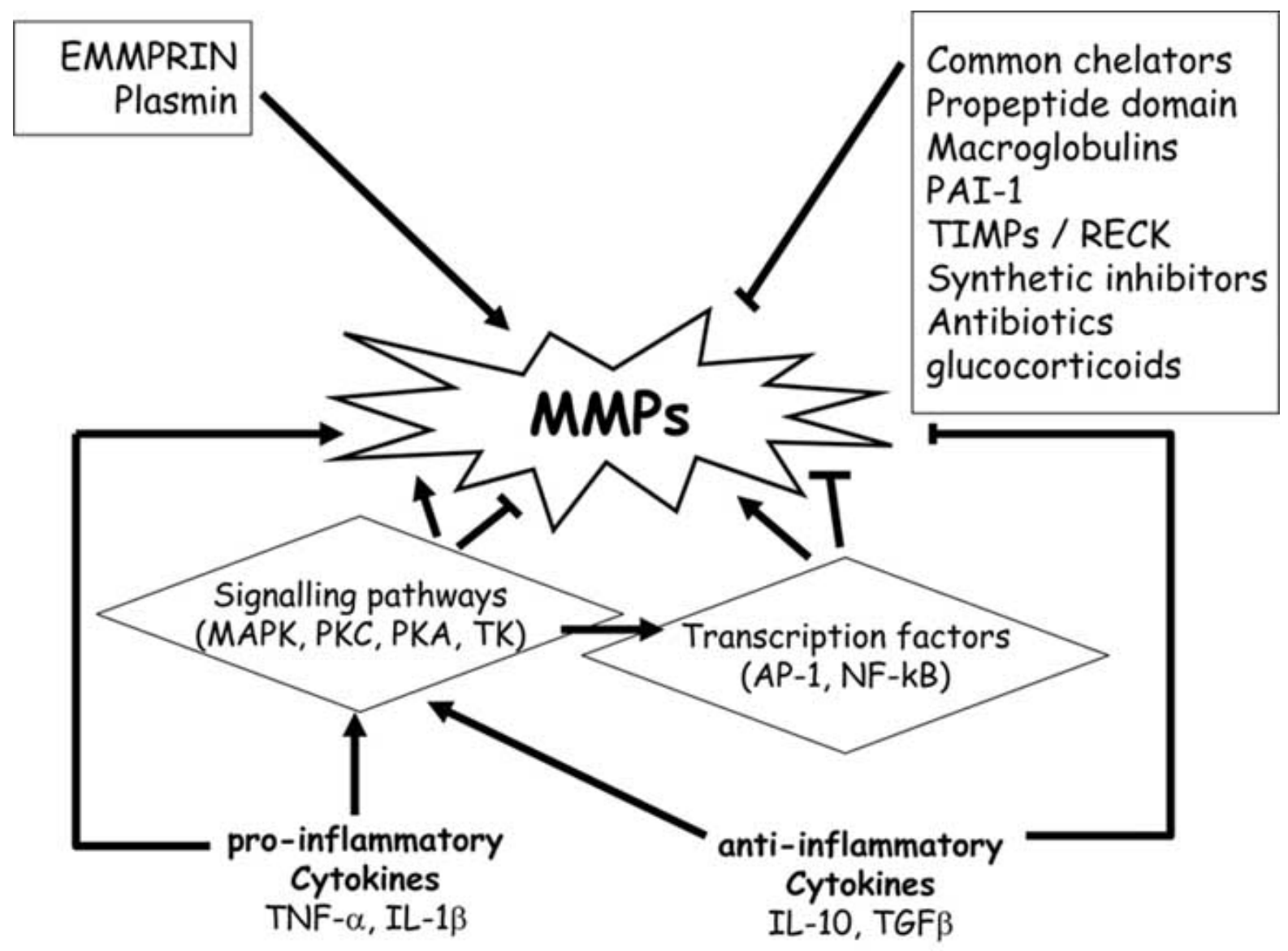

Fig. (1). Overview of regulation of MMPs expression, production and activity. Plasmin, extracellular matrix metalloproteinase inducer (EMMPRIN) and MMPs themselves occur as endogenous MMPs inducers and activators. In pathological conditions proinflammatory cytokines, such as IL- $1 \beta$ and TNF- $\alpha$, should increase MMPs level through signalling pathway and transcription factors activation whereas some anti-inflammatory cytokines, such as IL-10 and TGF $\beta$, decrease MMPs expression. Inhibition of MMPs should also occurs through endogenous tissue inhibitors of MMPs (TIMPs) and reversion-inducing-cysteine-rich protein with Kazal motifs (RECK) as well as propeptide domain, common chelators, plasminogen activator inhibitor and macroglobulins. Furthermore, antibiotics and glucocorticoids are also known to have properties of inhibition of MMPs. Therapeutical benefit of MMPs inhibition involved the development of several synthetic inhibitors that binds reversibly at the MMP active region utilising a zinc-binding group.

AP-1, activator protein-1; MAPK, mitogen activated protein kinase; NF- $\kappa \mathrm{B}$, nuclear factor $\kappa \mathrm{B}$; PAI-1, plasminogen activator inhibitor; PKC, protein kinase C; PKA, protein kinase A; TK, tyrosine kinase.

\section{Antibiotics}

A number of natural antibiotics have been used as inhibitors of MMPs; in most cases these seem to act by chelation. Doxycycline and other derivatives of tetracycline are potent MMP inhibitors. Inhibition of MMPs by doxycycline occurs independently of antimicrobial activity [72]. The beneficial effect of doxycycline on ECM degradation in animal models and human has been attributed to the inhibition of MMPs [73]. Doxycycline may reduce airway inflammation and hyperresponsiveness through phosphatidylinositol 3-kinase pathway in a murine model of TDI-induced asthma [74]. Furthermore tetracycline 3, a potent inhibitor of neutrophil MMPs and neutrophil elastase with minimal toxicity, prevent lung injury in porcine endotoxin-induced airway respiratory distress syndrome (ARDS) model [75]. The tetracycline derivative, doxycycline, is the only active site MMP inhibitor on the market today, and it is used as a treatment for periodontal disease, an inflammatory condition similar to lung diseases, in which MMPs degrade gingival tissues and bone resulting in tooth loss [76].

\section{Propeptide Domain}

The propeptide domain from MMP, containing a conserved sequence in which the cysteine is coordinated to the zinc atom at the active site, was able to inhibit activated MMP. Indeed the loss of this profragment converts the latent proenzyme species into a stable active enzyme species. Free cysteine was also an effective inhibitor, whereas reduced glutathione was a less effective inhibitor. Stetler-Stevenson et al. [77] were the first to pursue this idea. They prepared a peptide of 14 residues matching the MMP-2 propeptide and demonstrated this conserved prosegment sequence is an inhibitor of active MMP-2. 
A novel class of cyclic peptides containing an HWGF motif was described. They are specific inhibitors of MMP-2 and MMP-9. Although the inhibitory mechanism of the CTTHWGFTLC peptide is still unclear, it is tempting to speculate that the tryptophan residue in the HWGF motif may bind to the hydrophobic pocket of the substrate cleft in the enzyme and that the histidine residue may act as a ligand for the catalytic zinc ion. Novel gelatinase inhibitors such as CTTHWGFTLC specifically inhibit MMP-2 and MMP-9 [78].

The autocatalytic processing of MT1-MMP on the cell surface leading to the release of a major 44-kDa membranetethered degradation form lacking the catalytic domain and, concomitantly a fragment of the catalytic domain is released into the extracellular space as an inactive $18-20-\mathrm{kDa}$ soluble form [79]. The non-autocatalytic shedding leads to the release of the entire ectodomain by a yet unknown protease. The autocatalytic shedding is inhibited by the natural MT1MMP inhibitors, TIMP-2 and TIMP-4, and high affinity synthetic MMP inhibitors like marimastat. Consequently, these inhibitors stabilise active MT1-MMP on the cell surface.

\section{Macroglobulins}

Human $\alpha_{2}$-macroglobulin is a large plasma glycoprotein that binds nonspecifically to active proteinases and inactivates them $[80,81,82]$. Alpha2-macroglobulins inactivate susceptible proteinases by entrapment following cleavage of the bait region [83, 84]. The proteinase cleaves one or more bonds in the 40 residue bait region and thereby initiates a conformational change that lead to entrapment of the proteinase. Although the catalytic activity of the MMPs is not inhibited per se, their physical entrapment keeps the enzyme from interacting with natural substrates, and the $\alpha 2$ macroglobulin/MMP-2 complex is eventually endocytosed and permanently cleaved [84].

\section{Plasminogen Activator Inhibitor-1}

Plasminogen activator inhibitor (PAI)-1 is the main inhibitor of the fibrinolytic system and is known to play an essential role in tissue remodelling. PAI-1 inhibits fibrinolysis by blocking the conversion of plasminogen to plasmin [85]. PAI-1 also plays a role in the control of MMP activation. PAI-1 promotes collagen deposition in the airways of ovalbumin-challenged mice by inhibiting the activity of MMP-9. After ovalbumin challenge, MMP-9 activity was approximately 3-fold higher in lung tissue and BAL fluids from PAI-1-deficient mice than wild-type mice. This suggests that PAI-1 may promote ECM deposition by inhibiting fibrinolysis and MMP-9 activity [40].

\section{Tissue Inhibitors of MMPs}

In the extracellular matrix, specific tissue inhibitors of MMPs (TIMPs) control the enzyme activity by forming a stoichiometric enzyme-inhibitor complex with the activated enzyme. The endogenous inhibitors of MMPs maintain a physiologic balance between active and inactive MMPs in the body. Natural inhibitors of MMP activity were originally considered for clinical development. The major function of the TIMPs is the inhibition of proteolytic activity. All TIMPs inhibit all MMPs. Accelerated breakdown of ECM occurs in various lung pathological processes, including inflammation, chronic degenerative diseases and tumour invasion. It seems logical to use MMPs inhibitors in the treatment of asthma and COPD, both diseases being characterised by an excess in proteolytic activity, resulting from an increase in MMPs [86]. TIMPs bind tightly to the active sites of nearly all MMPs and block their activity. However, under disease states, these endogenous inhibitors often become saturated with MMPs, resulting in elevated levels of active MMPs. Initially, enzyme inhibitors were designed to mimic MMP substrates, blocking the active sites of MMPs [50]. Although numerous inhibitors have shown promise early on, unfortunately, most have been plagued by adverse reactions and side effects. Because the catalytic domains of MMPs are highly conserved, active site inhibitors typically block a broad spectrum of MMPs, and side effects may be caused by the inhibition of MMPs required for normal physiology [87].

TIMP-1 and TIMP-2 can inhibit tumour growth, invasion, and metastasis in experimental models which has been associated with their MMP inhibitory activity. Recent developments in TIMP research suggest that TIMP-1 and TIMP-2 are multifunctional proteins with diverse actions. Both inhibitors exhibit growth factor-like activity and can inhibit angiogenesis. Structure-function studies have separated the MMP inhibitory activity of TIMP-1 from its growth promoting effect. TIMP-3 is the only member of the TIMP family which is found exclusively in the extracellular matrix (ECM). It is regulated in a cell cycle-dependent fashion in certain cell types and may serve as a marker for terminal differentiation. The most recently discovered TIMP, TIMP-4, may function in a tissue-specific fashion in extracellular matrix hemostasis. TIMPs are important in malignancy, regulation of cell morphology and organ morphogenesis, and all sorts of tissue remodelling.

An interesting approach would be to administer the endogenous antiproteases TIMPs by viral vector gene delivery or as recombinant proteins. However, viral vector gene delivery is unlikely to provide sufficient protein and the production of large amounts of recombinant protein is most probably not cost effective. For this reason, there is an increased interest in the development of synthetic MMP inhibitors.

\section{Synthetic Inhibitors of MMPs}

The first synthetic MMP inhibitors (MMPIs) were developed in the early 1980s. These were pseudopeptide derivatives based on the structure of collagen molecule at the site of initial cleavage by interstitial collagenase. The inhibitor binds reversibly at the MMP active region utilising a zinc-binding group. Several zinc-binding groups have been tested, with hydroxamates appearing to be the most useful and being employed in the majority of inhibitors currently in development. If a hydroxamate inhibitor is first bound to MMP, this occludes the active centre and TIMP cannot bind [89].

Synthetic inhibitors were used in animal models in 1988, when a broad-spectrum MMPI called SC-44463 blocked experimental metastasis in mice [90]. An important advancement in the clinical development of MMPIs occurred in 1992, when batimastat (BB-94), a broad-spectrum hydroxamic-acid derivative based on the structure of 
collagen, became the first MMPI to be tested in humans but its development was hampered by poor bioavailability [87]. The barrier of poor solubility was overcome by using intraperitoneal and intrapleural administration, which creates a depot of compound and sustained plasma levels. Chemical modification of this compound resulted in the synthesis of marimastat (BB-2516) which retains the activity of its predecessor but has excellent oral bioavailability. Furthermore, a large amount of preclinical data suggests that marimastat and other MMP inhibitors could have important role in the treatment of malignancy [91, 92]. Some of the synthetic MMP inhibitors have been evaluated in preclinical and clinical trials, mainly as a treatment option for cancer, including cancer of lung [2], and rheumatoid arthritis [93]. Periostat is the only inhibitor of MMPs that is licensed in the US for the treatment of periodontal disease. Other inhibitors are under investigation: marimastat for the treatment of pancreatic, gastric and lung cancer, prinomastat (AG-3340) for prostate and non small cell lung cancer, tanomastat for pancreatic and small cell lung cancer and neovastat for renal cell carcinoma and non small cell lung cancer [2]. However, most, if not all, synthetic MMP inhibitors lack specificity and the development of several of these drugs has been stopped owing to a lack of efficacy or to unwanted side effects such as musculoskeletal toxicity. It was reported that sustained treatment with marimastat resulted in crippling pain in the joints, starting with the hands and moving through the extremities. Prinomastat, a hydroxamic-acid derivative, is a potent and selective oral inhibitor of matrix metalloproteinase-2, $-9,-13$ and -14 and is relatively selective for gelatinase as compared with collagenase. Disappointingly it showed similar side-effects to marimastat. By contrast, BAY12-9566, a butanoic-acid analogue with a similar selectivity profile to prinomastat showed no musculoskeletal side effects, but has not been clinically effective. Identification of the enzymes responsible for the joint pain that is induced by MMPIs remains a high priority, as this activity limits the doses of compound that can be administered to patients [80]. This particular selectivity should represent an advantage for prinomastat in terms of efficacy/tolerability. Moreover, the combination of prinomastat and several chemotherapeutic agents was shown to induce additive effects. The drug is currently in phase III clinical trials for patients with non-small cell lung cancer in combination with paclitaxel and carboplatin, as well as in advanced hormone refractory prostate cancer in combination with mitoxantrone. The most common side effects are musculoskeletal pain and stiffness. These side effects generally stop with treatment interruption.

In 2000, virtually all the main pharmaceutical companies had MMPIs in clinical development. Now, in early 2006, the scene has cooled considerably owing to the failure of several phase III clinical trials to show any survival benefit of MMPI treatment, and, in the case of BAY12-9566, alarming reports that patients who were treated with an MMPI fared worse than their placebo-treated counterparts [2]. Several factors probably contributed to the failure of these early clinical trials, and these must be investigated before we can conclude that MMP inhibition has no therapeutic benefit. Side effects could be reduced by increasing selectivity for specific MMPs or by targeting delivery to the lung parenchyma. Among these are the persistent problems of specificity for the targeted MMP, and the need for assays to verify inhibition of target enzymes in vivo.

\section{Regulation of MMP Gene Expression}

An alternative approach is blocking the synthesis of MMPs at the level of gene expression. This strategy may allow for the targeted inhibition of these enzymes involved in a particular disease.

\section{Pro-Inflammatory Cytokines}

Blocking the action of inflammatory cytokines could have downstream effects on the expression of specific MMPs involved in inflammatory diseases, eliminating nonspecific effects on MMPs required for normal physiology. Biologic therapies directed against inflammatory cytokines have shown efficacy in pulmonary diseases. For example, antibody therapies directed against TNF- $\alpha$, infliximab and etanercept, reduce severe asthma [94] and idiopathic pulmonary fibrosis (IPF) [95]. In addition, targeting IL-1 with the recombinant human IL-1 receptor antagonist anakinra, improves interstitial lung disease symptoms [96]. Because IL-1 and TNF- $\alpha$ induce MMP-1, MMP-2, MMP-3 and/or MMP-9 expression during lung injury, it is likely that these therapies also reduce expression of these critical collagen-degrading enzymes [97-99]. However, the broad anti-inflammatory effects of these agents may suppress immune functions, leading to increased susceptibility to infections [100] and even lymphoproliferative disorders.

\section{Signalling Pathways}

Another strategy for blocking or activating MMP gene expression is to target the signalling pathways regulating these genes. It is, therefore, important to consider growth and/or invasion specific signalling cascade that could serve as targets for chemical regulators or dominant negative kinase mutants and antisense oligonucleotides. Although synthesis of MMPs shows a general, albeit differential, sensitivity to growth factors and cytokines [7, 101], and specific tyrosine kinase- [102], protein kinase C- [103, 104], protein kinase A- [99] and Src- [102] dependent mechanisms have been identified, the control of these enzymes by extracellular stimuli is largely unknown. A role for extracellular regulated kinase (ERK) in matrix remodelling has been shown using human fibroblasts, in which ERK was associated with inhibition of collagen type I expression [28]. Recently, Mercer et al. [105] have demonstrated a central role for ERK in cigarette smoke-induced MMP-1 activity in lung epithelia and in emphysema-associated pathologies. Regarding inhibition of MMP expression at the level of kinase pathways, it is possible that selective chemical inhibitors for distinct pathways (e.g. MAPK, PKC) will, hopefully, soon be available for initial clinical trials. Underwood et al. [106] have shown that the p38 inhibitor SB203580 reduces neutrophilia, inflammatory cytokines, MMP-9 and fibrosis in lung. In the same way, the selective inhibitor of JNK, SP600125, reduces neutrophil influx into the lungs and proinflammatory gene products, such as MMP-9 expression in bronchoalveolar lavage fluid stimulated with LPS [107]. Although these agents have shown some efficacy in pulmonary diseases models, it is evident that multiple signalling pathways regulate MMP 
expression. Therefore, combination therapies targeting multiple pathways might optimise the inhibition of MMP gene expression.

Over-expression of selective dual MAPK phosphatases have been shown to prevent MMP promoter activation [108110] which could also be used as a novel strategy to prevent activation of activator protein-1 (AP-1) and nuclear factor $\mathrm{\kappa B}$ (NF-KB) transcription factors and MMP promoter in vivo. Both IL- $1 \beta$ and TNF- $\alpha$, regulate the synthesis and activation of AP-1, through mitogen-activated protein kinase (MAPK) signalling pathways [111]. For example, the c-Jun Nterminal kinase (JNK) phosphorylates c-Jun and generates an active DNA-binding AP-1 complex. In response to inflammatory stimuli, AP-1 also induces the synthesis of cFos and c-Jun mRNAs. Another MAPK, p38, activates factors required for the synthesis and activation of AP-1 [111]. NF- $\kappa \mathrm{B}$ activation seems to be an important mechanism underlying both LPS-induced NO production, and also MMP-9 activity and resulting neutrophil recruitment [97, 112]. Then, the activation of NF- $\mathrm{KB}$ binding to various gene promoter regions appears to be a key molecular event in the initiation of LPS-induced pulmonary disease. Therefore, MAPK pathways are critical signalling mediators of inflammatory cytokines, and these pathways target factors required for the expression of MMPs.

\section{Natural Products}

Natural products have been characterised for their effects on MMP gene expression. Green tea catechins reduce MMP2 and MMP-9 levels [113]. Curcumin lowers MMP-1 and MMP-13 expression through mechanisms involving NFKB and AP-1 pathways, [97, 114]. Extracts from the plant tripterygium wilfordii Hook F (TWHF) also suppress the expression of these genes in chondrocytes [115]. Therefore, synthetic and natural product inhibitors of MMP gene expression might serve as therapeutic agents to reduce parenchyma destruction.

Another class of compounds that can decrease MMP gene expression are the triterpenoids, naturally occurring plant compounds formed by the cyclisation of squalene. Triterpenoids contain 30 carbon molecules arranged into rings, and their structures are reminiscent of steroid hormones. Oleanolic acid and its isoform, ursolic acid, are abundant triterpenoids isolated from plants such as ginseng, eucalyptus, and rosemary. Thousands of triterpenoids have been isolated from various plant species, and these compounds may be involved in host-defense mechanisms by protecting plants from pathogens. Triterpenoids have been critical components of Asian folk medicine for centuries, suggesting that they have beneficial properties, even though scientific studies indicate that naturally occurring triterpenoids lack potency. Numerous studies have shown beneficial activities of these compounds in animal models of cancer, liver disease, and atherosclerosis, suggesting that these interesting compounds may lead to the development of novel therapeutics [116].

\section{Nuclear Hormone Receptors and their Ligands}

Many compounds that inhibit MMP gene expression act through nuclear hormone receptors, a large family of ligandactivated transcription factors that regulate the expression of genes by binding to specific promoter sequences or interacting with other transcription factors [117]. These receptors have been implicated in diseases such as cancer and remodelling-associated pathologies. Recent efforts have focused on identifying their target genes and developing selective ligands to modulate the activity of these genes. MMPs are regulated by a number of nuclear hormone receptors and their ligands. Although the promoters of MMP genes lack hormone response elements, a number of nuclear receptors and their ligands regulate the transcription of these genes through protein-protein interactions between nuclear receptors and other transcription factors, such as AP-1 [118] and NFKB [119]. Although glucocorticoids are potent inhibitors of MMP gene expression, these compounds also have broad anti-inflammatory effects and are associated with numerous side effects in vivo, limiting their use for longterm therapy. Similarly, vitamin A derivatives, such as naturally occurring all-trans retinoic acid regulate expression of MMPs. Retinoids interact with retinoid acid receptors (RARs) and retinoid X receptors (RXRs), which form heterodimers [118]. MMP-1 and MMP-2 are repressed by retinoids, through RAR/RXR interactions and suppression of c-Jun transcriptional activity [120]. However, like glucocorticoids, retinoids also are associated with side effects, and their clinical use has been limited to skin diseases such as acne and psoriasis, and to the chemotherapy of some cancers, such as bronchial carcinoma [121, 122]. More recently, novel synthetic retinoid derivatives have been synthesised, and these may reduce toxicity and inhibit MMP gene expression through more selective pathways, representing new designer retinoids for the future $[121,122]$. A RAR $\alpha$ antagonist suppressed MMP-1 and MMP-2 synthesis in the melanoma cell line [123]. The retinoids represent still another group of related compounds with clinical potential since they bind specifically to RXRs and not to RARs, thereby conferring specificity in terms of target genes [121,124].

\section{Transcriptional Regulation of MMP Genes}

Matrix metalloproteinases are expressed in a tissuespecific manner, and their synthesis is tightly regulated at the level of gene expression. Understanding these regulatory mechanisms should be from the rationale for developing gene-specific therapies to suppress MMP gene expression. In several tissues including lung, some MMPs are expressed constitutively (MMP-2, MT1-MMP), although others (MMP-1, MMP-3, MMP-9, and MMP-13) are induced by inflammatory cytokines such as IL-1 and TNF- $\alpha$. The promoters of the MMP genes have been well characterised, and AP-1 was demonstrated as a key regulator of MMP transcription. AP-1 is a transcription factor complex composed of c-Fos/c-Jun heterodimers or c-Jun/c-Jun homodimers [80]. The MMP-1, MMP-3, MMP-9, and MMP-13 promoters contain a proximal AP-1 enhancer element at $-70 \mathrm{bp}$, and this site is critical for expression [80]. AP-1 proteins cooperate with other transcription factors, such as erythroblastosis 26 transformation-specific (Ets) proteins, to cooperatively activate transcription of these genes [125]. Newly characterised Ets target genes such as tenascin- $\mathrm{C}$ and collagen type I suggest their role in diseases characterised by aberrant collagen deposition (i.e. lung fibrosis). Ets factors may function as activators or as repressors via association with specific cofactors depending on the promoter context. The role of Ets factors in tumour 
invasion is mainly related to transcriptional activation of enzymes that are involved in ECM degradation such as serine proteases, MMPs and TIMPs. Recent studies suggest that the function of Ets factors may not be limited to regulating genes involved in the degradative pathways [126].

$\mathrm{NF}-\kappa \mathrm{B}$ is another cytokine-induced transcription factor with an important role in the regulation of MMP expression. $\mathrm{NF}-\kappa \mathrm{B}$ is composed of $\mathrm{p} 50$ and p65 subunits, which translocate into the nucleus upon phosphorylation of the

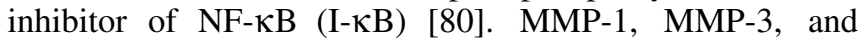
MMP-9 promoters contain binding sites for NF- $\kappa \mathrm{B}$, and activation of $\mathrm{NF}-\kappa \mathrm{B}$ is required for transcriptional induction of these genes [97, 112, 114]. However MMP-2 promoter seems to be very different from other MMPs promoter. MMP-2 is constitutively expressed and not regulated by AP1 and NF- $\kappa$ B. No NF- $\mathrm{BB}$ site has been identified in MMP-2 as in MT1-MMP promoters, but recently a p53 binding site has been reported, which can mediate MMP-2 transactivation after DNA damage [127]. NF- $\kappa \mathrm{B}$ can also transactivate $\mathrm{p} 53$ [128] and would be able to indirectly induce MMP-2 transcription.

\section{Transforming Growth Factor- $\beta$}

Transforming growth factor $\beta$ (TGF- $\beta$ ) is another regulator of MMP expression, which may be a therapeutic target. It is expressed in mesenchymal airways cells and in inflammatory cells, where it could have both stimulatory and repressive effects $[99,129]$. TGF- $\beta$ signals through the TGF- $\beta$ receptor complex and activates smads, which in turn translocate into the nucleus and regulate gene expression [130]. Smad complexes consist of receptor-activated smads $(\operatorname{smad} 2, \operatorname{smad} 3)$ that are phosphorylated by the TGF- $\beta$ receptor, and co-smads $(\operatorname{smad} 4)$ that dimerise with the phosphorylated smads. TGF- $\beta$ signalling is inhibited by smad7, which binds to the TGF- $\beta$ receptor and blocks the phosphorylation of receptor-activated smads [130]. In response to TGF- $\beta$, smads regulate the expression of MMPs, either by binding directly to promoter elements or through interactions with other transcription factors [131]. The MMP-1 and MMP-3 promoters contain a TGF- $\beta$ inhibitory element responsible for repression by TGF- $\beta$ [125]. Smad3 represses MMP-1 expression [132]. Smad3 null mice (knockout) develop progressive age-related increases in the size of alveolar spaces, associated with high spontaneous presence of matrix metalloproteinases (MMP-9 and MMP12) in the lung [133]. Furthermore interactions between smads and AP-1 regulate MMP-13 [134]. In summary, AP1 , Ets, NF- $\kappa \mathrm{B}$, and smad proteins play important roles in the regulation of MMP gene expression, and modulation of these transcription factors may alter the levels of MMPs and impact lung disease processes.

\section{Regulation of Activity and Expression of TIMPs}

Members of the TIMP gene family may make important contributions to the response to lung injury. Levels of TIMP-1 are increased in the BAL fluid recovered from patients with ARDS [135]. Increased TIMPs immunoreactive protein levels have been identified in the lung biopsies of patients with ARDS or IPF $[59,136]$. Experimental models also suggest a potential role for TIMPs in the response to lung injury, showing a significant and durable increase in TIMP-1 expression in bleomycin-induced lung injury [137,
138]. TIMP-1 expression by lung parenchymal cells and inflammatory cells seems to be crucial in limiting the response to acute injury. However, TIMP-1-deficient phenotype in response to acute lung injury was not found in TIMP-2-deficient mice [139]. These results underline TIMP1 functions in pathogenesis of some lung diseases. So TIMPs, and especially TIMP-1, should represent a potential target for therapeutic intervention aimed at the modification of lung pathology by restoring the physiological balance between MMPs and TIMPs.

\section{Regulation of Activity and Expression of EMMPRIN}

The capacity of EMMPRIN to stimulate MMPs production and expression is clearly demonstrated in several studies concerning in vivo and in vitro models of lung pathological processes such as cancer, emphysema [24] and pulmonary fibrosis [22]. Inhibition of EMMPRIN-induced activation of MMPs should generate a great deal of therapeutical interest.

HAb18G is a new hepatoma-associated antigen recently cloned by hepatoma monoclonal antibody HAb18 screening from human hepatocellular carcinoma cDNA library [140]. Like CD147/EMMPRIN, HAb18G is a highly glycosylated transmembrane protein of $60 \mathrm{kDa}$ with an ectodomain consisting of two regions exhibiting the characteristics of the immunoglobulin superfamily [140]. Effectively, the amino acid sequence of $\mathrm{HAb} 18 \mathrm{G}$ is identical to that of CD147/EMMPRIN and it was demonstrated that HAb18G stimulates fibroblast cells and PMA differentiated THP-1 to produce elevated levels of several MMPs including MMP-1, MMP-2, and MMP-9 [140, 141]. In the light of these findings, a HAb18G/CD147 antagonistic peptide, AP-9, was developed. The elevated expression and activation of MMPs from THP-1 cells were blocked by AP-9 [141]. Recently, metuximab, a murine HAb18 F(ab')2 fragment specific for EMMPRIN, has been developed in the iodine ${ }^{131}$-labeled form and is being tested for safety and clinical efficacy in hepatocellular carcinoma in China [13].

The abnormally high levels of EMMPRIN in cancer cells have also been attributed to dysregulation of epithelial growth factor receptor (EGFR) signalling. Indeed EMMPRIN synthesis and MMP induction are upregulated by the activation of the EGFR signalling pathways [142]. The signalling events downstream of EMMPRIN interactions that result in stimulation of MMP production are not yet established but MAPK p38 has been implicated in induction of MMP-1 production [28] and activation of 5lipoxygenase and phospholipase A2 in MMP-2 production [143]. In addition, a disruptive role for EMMPRIN in calcium mobilisation through G-protein sensitive pathways has been demonstrated in tumour cells, and it suggested that this effect of EMMPRIN enhances the metastatic potential of hepatocarcinoma cells [13]. The possibility of developing EMMPRIN inhibitors for treatment of cancer should be a future consideration.

\section{CONCLUSION}

The expression, production and activity of MMPs have interesting implications for the use of MMP regulators as therapeutic agents. A better understanding of the molecular mechanism regulating the induction and repression of 
specific MMP may provide valuable insights for developing therapeutic agents. Endogene regulators such as TIMP, EMMPRIN or RECK, and inducers of MMP expression such as inflammatory cytokines, as well as signalling pathways involved, should be targeted to modulate MMP expression. The expression of some MMPs can be blocked by TGF- $\beta$, glucocorticoid hormones and the vitamin A analogues, retinoids. However, all of these compounds act on many genes and result in undesirable side effects and toxicities. The emergence of targeted ligands for specific retinoid receptors has begun to resolve these difficulties, as has the appearance of plant derivatives that could selectively inhibit one MMP over another. Insights might be gained as to the preference for a general MMP inhibitor as opposed to an inhibitor designed to be specific for certain MMP family members. The generation of mice that are deficient for many MMPs, and their use in sophisticated genetic models of disease will provide important information about which MMP family members or regulators to target for therapeutic applications. Although the role of MMPs as mediators of biology and pathology, and as targets for lung diseases therapies is clearly underline, all the possibility of regulation for MMPs expression, production and activation have not been discovered, and it will be essential to understand the many ways in which these enzymes can influence complex biological and pathological processes.

\section{REFERENCES}

[1] Woessner, J.F.; Nagase, H. Matrix Metalloproteinases and TIMPs; Oxford Univ. Press: New-York, 2000

[2] Coussens, L.M.; Fingleton, B.; Matrisian, L.M. Science 2002, 295, 2387.

[3] Fowlkes, J.L.; Winkler, M.K. Cytokine Growth Factor Rev. 2002, $13,277$.

[4] Lagente, V.; Boichot, E.; Corbel, M.; Artola, M.; CauletMaugendre, S.; Planquois, J-M. Curr. Top. Pharmacol. 2003, 7, 91

[5] Sato, H.; Takino, T.; Kinoshita, T.; Imai, K.; Okada, Y.; Stetler Stevenson, W.G.; Seiki, M. FEBS Lett. 1996, 385, 238.

[6] Nelson, K.K.; Melendez, J.A. Free Radic. Biol. Med. 2004, 37, 768.

[7] Busse, W.; Elias, J.; Sheppard, D.; Banks-Schlegel, S. Am. J. Respir. Crit. Care Med. 1999, 160, 1035.

[8] Parks, W.C. Eur. Respir. J. Suppl. 2003, 44, $36 \mathrm{~s}$.

[9] Elshaw, S.R.; Henderson, N.; Knox, A.J.; Watson, S.A.; Buttle, D.J.; Johnson, S.R. Br. J. Pharmacol. 2004, 142, 1318.

[10] Dunsmore, S.E.; Saarialho-Kere, U.K.; Roby, J.D.; Wilson, C.L.; Matrisian, L.M.; Welgus, H.G.; Parks, W.C. J. Clin. Invest. 1998, $102,1321$.

[11] Ellis, S.; Nabeshima, K.; Biswas, C. Cancer Res. 1989, 49, 3385.

[12] Muramatstu, T.; Miyauchi, T. Histol. Histopathol. 2003, 18, 981.

[13] Jiang, J.L.; Zhou, Q.; Yu, M.K.; Ho, L.S.; Chen, Z.N.; Chan, H.C. J. Biol. Chem. 2001, 276, 46870.

[14] Kataoka, H.; DeCastro, R.; Zucker, S.; Biswas, C. Cancer Res. 1993, 53, 3154 .

[15] Van den Oord, J.; Paemen, L.; Opdenakker, G.; De Wolf-Peeters, C. Am. J. Pathol. 1997, 151, 665.

[16] Zucker, S.; Hymowitz, M.; Rollo, E.E.; Mann, R.; Conner, C.E.; Cao, J.; Foda, H.D.; Tompkins, D.C.; Toole, B.P. Am. J. Pathol. 2001, 158, 1921.

[17] Caudroy, S.; Polette, M.; Tournier, J.M.; Burlet, H.; Toole, B.; Zucker, S.; Birembaut, P. J. Histochem. Cytochem. 1999, 47, 1575.

[18] Polette, M.; Gilles, C.; Marchand, V.; Lorenzato, M.; Toole, B.; Tournier, J.M.; Zucker, S.; Birembaut, P. J. Histochem. Cytochem. 1997, 45, 703.

[19] Spinale, F.G.; Coker, M.L.; Heung, L.J.; Bond, B.R.; Gunasinghe, H.R.; Etoh, T.; Goldberg, A.T.; Zellner, J.L.; Crumbley, A.J. Circulation 2000, 102, 1944.
[20] Gabison, E.E.; Mourah, S.; Steinfels, E.; Yan, L.; Hoang-Xuan, T.; Watsky, M.A.; De Wever, B.; Calvo, F.; Mauviel, A.; Menashi, S. Am. J. Pathol. 2005, 166, 209.

[21] Major, T.C.; Liang, L.; Lu, X.; Rosebury, W.; Bocan, T.M. Arterioscler. Thromb. Vasc. Biol. 2002, 22, 1200.

[22] Betsuyaku, T.; Kadomatsu, K.; Griffin, G.L.; Muramatsu, T.; Senior, R. Am. J. Respir. Cell Mol. Biol. 2003b, 28, 600.

[23] Foda, H.D.; Rollo, E.; Drews, M.; Conner, C.; Appelt, K.; Shalinsky, D.R.Am. J. Respir. Cell Mol. Biol. 2001, 25, 717.

[24] Betsuyaku, T.; Tanino, M.; Nagai, K.; Nasuhara, Y.; Nishimura, M.; Senior, R. Am. J. Respir. Crit. Care Med. 2003a, 24, 26.

[25] Lumb, P.D.; Suvarna, S.K. Histopathology 2004, 44, 345.

[26] Fukuda, Y.; Ishizaki, M.; Kudoh, S.; Kitaichi, M.; Yamanaka, N. Lab. Invest. 1998, 78, 687.

[27] Li, R.; Huang, L.; Guo, H.;Tool, B. FEBS Lett. 1998, 441, 88.

[28] Lim, M.; Martinez, T.; Jablons, D.; Cameron, R.; Guo, H.; Toole, B.; Li, J.D.; Basbaum, C. FEBS Lett. 1998, 441, 88.

[29] Sameshima, T.; Nabeshima, K.; Toole, B.P.; Yokogami, K.; Okoda, Y.; Goya, T.; Koono, M.; Wakisaka, S. Cancer Lett. 2000, 157, 177-184.

[30] Sun, J.; Hemler, M.E. Cancer Res. 2001, 61, 2276.

[31] Ogata, Y.; Enghild, J.J.; Nagase, H. J. Biol. Chem. 1992, 267, 3581.

[32] Suzuki, K.; Enghild, J.J.; Morodomi, T.; Salvesen, G.; Nagase, H. Biochemistry 1990, 29, 10261.

[33] He, C.S.; Wilhelm, S.M.; Pentland, A.P.; Marmer, B.L.; Grant, G.A.; Eisen, A.Z.; Goldberg, G.I. Proc. Natl. Acad. Sci. USA 1989, 86, 2632.

[34] Liu, Z.; Zhou, X.; Shapiro, S.D.; Shipley, J.M.; Diaz, L.A.; Senior, R.M.; Werb, Z. Cell 2000, 102, 647.

[35] Parks, W.C.; Shapiro, S.D. Respir. Res. 2001, 2, 10.

[36] Bertozzi, P.; Astedt, B.; Zenzius, L.; Lynch, K.; Le Maire, F.; Zapol, W.; Chapman, H.A. N. Engl. J. Med. 1990, 322, 890.

[37] Chapman, H.A.; Allen, C.L.; Stone, O.L. Am. Rev. Respir. Dis. 1986, $133,437$.

[38] Hasday, J.D.; Bachwich, P.R.; Lynch, J.P.; Sitrin, R.G. Exp. Lung Res. 1988, 14, 261.

[39] Viscardi, R.M.; Broderick, K.; Sun, C.C.; Yale-Loehr, A.J.; Hessamfar, A.; Taciak, V.; Burke, K.C.; Koenig, K.B.; Idell, S. Am. Rev. Respir. Dis. 1992, 146, 492.

[40] Cho, S.H.; Ryu, C.H.; Oh, C.K. Exp. Biol. Med. 2004, 229, 138.

[41] Keski-Oja, J.; Lohi, J.; Tuuttila, A.; Tryggvason, K.; Vartio, T. Exp. Cell Res. 1992, 202, 471.

[42] Takahashi, C.; Sheng, Z.; Horan, T.P.; Kitayama, H.; Maki, M.; Hitomi, K.; Kitaura, Y.; Takai, S.; Sasahara, R.M.; Horimoto, A.; Ikawa, Y.; Ratzkin, B.J.; Arakawa, T.; Noda, M. Proc Natl Acad Sci U S A 1998, 95, 13221.

[43] Oh, J.; Takahashi, R.; Kondo, S.; Mizoguchi, A.; Adachi, E.; Sasahara, R.M.; Nishimura, S.; Imamura, Y.; Kitayama, H.; Alexander, D.B.; Ide, C.; Horan, T.P.; Arakawa, T.; Yoshida, H.; Nishikawa, S.; Itoh, Y.; Seiki, M.; Itohara, S.; Takahashi, C.; Noda, M. Cell 2001, 107, 789.

[44] Rhee, J.S.; Coussens, L.M. Trends Cell Biol. 2002, 12, 209.

[45] Furumoto, K.; Arii S.; Mori, A.; Furuyama, H.; Gorrin Rivas, M.J.; Nakao, T.; Isobe, N.; Murata, T.; Takahashi, C.; Noda, M.; Imamura, M. Hepatology 2001, 33, 189.

[46] Span, P.N.; Sweep, C.G.; Manders, P.; Beex, L.V.; Leppert, D.; Lindberg, R.L. Cancer 2003, 97, 2710.

[47] Masui, T.; Doi, R.; Koshiba, T.; Fujimoto, K.; Tsuji, S.; Nakajima, S.; Koizumi, M.; Toyoda, E.; Tulachan, S.; Ito, D.; Kami, K.; Mori, T.; Wada, M.; Noda, M.; Imamura, M. Clin. Cancer Res. 2003, 9, 1779 .

[48] Takenaka, K.; Ishikawa, S.; Yanagihara, K.; Miyahara, R.; Hasegawa, S.; Otake, Y.; Morioka, Y.; Takahashi, C.; Noda, M.; Ito, H.; Wada, H.; Tanaka, F. Ann. Surg. Oncol. 2005, 12, 817.

[49] Hautamaki, R. D.; Kobayashi, D. K.; Senior, R. M.; Shapiro, S. D. Science 1997, 277, 2002.

[50] Nelson, A.R.; Fingleton, B.; Rothenberg, M.L.; Matrisian, L.M. J. Clin. Oncol. 2000, 18, 1135.

[51] Sternlicht, M. D.; Bergers, G. Emerg. Therap. Targets 2000, 4, 609.

[52] Barnes, P.J. N. Engl. J. Med. 2004, 350, 2635.

[53] Daheshia, Curr. Med. Res. Opin. 2005, 21, 587.

[54] Pons, A.R.; Sauleda, J.; Noguera, A.; Pons, J.; Barceló, B.; Fuster, A.; Agustí, A.G.N. Eur. Respir. J. 2005, 26, 60.

[55] Barnes, P.J.; Stockley, R.A. Eur. Respir. J. 2005, 25, 1084. 
[56] Basset, F.; Ferrans, V.J.; Soler, P.; Takemura, T.; Fukuda, Y.; Crystal, R.G. Am. J. Pathol. 1986, 122, 443.

[57] Gadeck, J.E.; Kelman, J.A.; Fens, G.A.; Weinberger, S.E.; Horwizt, A.L.; Reynolds, H.Y. N. Engl. J. Med. 1979, 301, 737.

[58] Lemjabbar, H.; Gosset, P.; Lechapt-Zalcman, E.; FrancoMontoya, M.L.; Wallaert, B.; Harf, A.; Lafuma, C. Am. J. Respir. Cell Mol. Biol. 1999, 20, 903.

[59] Selman, M.; Ruiz, V.; Cabrera, S.; Segura, L.; Ramírez, R.; Barrios, R.; Pardo, A. Am. J. Physiol. Lung Cell Mol. Physiol. 2000, 279, L562.

[60] Stetler-Stevenson, W.G.; Yu, A.E. Semin. Cancer Biol. 2001, 11, 143.

[61] Turpeenniemi-Hujanen, T. Biochimie 2005, 87, 287.

[62] Canete-Soler, R.; Litzky, L.; Lubensky, I.; Muschel, R.J. Am. J. Pathol. 1994, 144, 518.

[63] Thomas, P.; Khokha, R.; Shepherd, F.A.; Feld, R.; Tsao, M.S. J. Pathol. 2000, 190, 150.

[64] Brown, P.D.; Bloxidge, R.E.; Stuart, N.S.A.; Gatter, K.C.; Carmichael, J. J. Natl. Cancer Inst. 1993, 85, 574.

[65] Kodate, M.; Kasai, T.; Hashimoto, H.; Yasumoto, K.; Iwata, Y.; Manabe, H. Pathol. Int. 1997, 47, 461.

[66] Herbst, R.S.; Yano, S.; Kuniyasu, H.; Khuri, F.R.; Bucana, C.D.; Guo, F.; Liu, D.; Kemp, B.; Lee, J.J.; Hong, W.K.; Fidler, I.J. Clin. Cancer Res. 2000, 6, 790.

[67] Cox, G.; Jones, J.L.; O'Bryne, K.J. Clin. Cancer Res. 2000, 6, 2349.

[68] Sienel, W.; Hellers, J.; Morresi-Hauf, A.; Lichtinghagen, R.; Mutschler, W.; Jochum, M.; Klein, C.; Passlick, B.; Pantel, K. Int J. Cancer 2003, 103, 647 .

[69] Aljada, I.S.; Ramnath, N.; Donohue, K.; Harvey, S.; Brooks, J.J.; Wiseman, S.M.; Khoury, T.; Loewen, G.; Slocum, H.K.; Anderson, T.M.; Beple, G.; Tan, D. J. Clin. Oncol. 2004, 22, 3218.

[70] Ylisirniö, S.; Höyhtyä, M.; Turpeenniemi-Hujanen, T. Anticancer Res. 2000, 20, 1311 .

[71] Souza, A.P.; Gerlach, R.F.; Line, S.R.P. Dent. Mater. 2000, 16 , 103.

[72] Golub, L.M.; Ramamurthy, N.S.; McNamara, T.F.; Greenwald, R.A.; Rifkin, B.R. Crit. Rev. Oral Biol. Med. 1991, 2, 297.

[73] Greenwald, R.A.; Moak, S.A; Ramamurthy, N.S.; Golub, L.M. J. Rheumatol. 1992, 19, 927.

[74] Lee, K.S.; Jin, S.M.; Kim, S.S.; Lee, Y.C. J. Allergy Clin. Immunol. 2004, 113, 902 .

[75] Carney, D.E.; McCann, U.G.; Schiller, H.J.; Gatto, L.A.; Steinberg, J.; Picone, A.L.; Nieman, G.F. J. Surg. Res. 2001, 99, 245.

[76] Greenwald, R.A. Ann. N. Y. Acad. Sci. 1999, 878, 413.

[77] Stetler-Stevenson, W.G.; Talano, J.A.; Gallagher, M.E.; Krutzsch, H.C.; Liotta, L.A. Am. J. Med. Sci. 1991, 302, 163

[78] Koivunen, E.; Arap, W.; Valtanen, H.; Rainisalo, A.; Medina, O.P.; Heikkila, P.; Kantor, C.; Gahmberg, C.G.; Salo, T.; Konttinen, Y.T.; Sorsa, T.; Ruoslahti, E.; Pasqualini, R. Nat. Biotechnol. 1999, 17, 768.

[79] Osenkowski, P.; Meroueh, S.O.; Pavel, D.; Mobashery, S.; Fridman, R. J. Biol. Chem. 2005, 280, 26160.

[80] Brinckerhoff, C.E.; Matrisian, L.M. Nat. Rev. Mol. Cell. Biol. 2002, 3, 207.

[81] Mengshol, J.A.; Mix, K.S.; Brinckerhoff, C.E. Arthritis Rheum 2002, 46,13

[82] Nagase, H.; Woessner, J.F. J. Biol. Chem. 1999, 274, 21491

[83] Sotturp-Jensen, L. J. Biol. Chem. 1989, 264, 11539.

[84] Birkedal-Hansen, H. Curr. Opin. Cell Biol. 1995; 7, 728.

[85] Collen, D. Thromb. Haemost. 1999, 82, 259.

[86] Demedts, I.K.; Brusselle, G.G.; Bracke, K.R.; Vermaelen, K.Y.; Pauwels, R.A. Curr. Opin. Pharmacol. 2005, 5, 257.

[87] Brown, P.D. Expert Opin. Investig. Drugs 2000, 9, 2167.

[88] Gomez, D.E.; Alonso, D.F.; Yoshiji, H.; Thorgeirsson, U.P. Eur. J. Cell Biol. 1997, 74, 111.

[89] Cuniasse, P.; Devel, L.; Makaritis, A.; Beau, F.; Georgiadis, D.; Matziari, M.; Yiotakis, A.; Dive, V. Biochimie 2005, 87, 393.

[90] Reich, R.; Stratford, B.; Klein, K.; Martin, G.R.; Mueller, R.A.; Fuller, G.C. Ciba Found Symp. 1988, 141, 193.

[91] Steward, W.P. Cancer Chemother. Pharmacol. 1999, 43 Suppl, S56.

[92] Steward, W.P.; Thomas, A.L. Expert Opin. Investig. Drugs 2000, 9,2913.

[93] Mix, K.S.; Sporn, M.B.; Brinckerhoff, C.E.; Eyre, D.; Schurman, D.J. Clin. Orthop. Relat. Res. 2004, 427, S129.
[94] Howarth, P.H.; Babu, K.S.; Arshad, H.S.; Lau, L.C.; Buckley, M.G.; McConnell, W.; Beckett, P.; Ali, M.A.; Chauhan, A.; Wilson, S.J.; Reynolds, A.; Davies, D.E.; Holgate, S.T. Thorax 2005, 60, 1012.

[95] Selman, M.; Thannickal, V.J.; Pardo, A.; Zisman, D.A.; Martinez, F.J.; Lynch, J.P. Drugs 2004, 64, 405.

[96] Efthimiou, P.; Markenson, J.A. South Med. J. 2005, 98, 192.

[97] Hozumi, A.; Nishimura, Y.; Nishiuma, T.; Kotani, Y.; Yokoyama, M. Am. J. Physiol. Lung Cell Mol. Physiol. 2001, 281, L1444.

[98] Sasaki, M.; Kashima, M.; Ito, T.; Watanabe, A.; Izumiyama, N.; Sano, M.; Kagaya, M.; Shioya, T.; Miura, M. Mediators Inflamm. 2000, 9, 155 .

[99] Martin-Chouly, C.A.E.; Astier, A.; Jacob, C.; Pruniaux, M.P.; Bertrand, C.; Lagente, V. Life Sci. 2004, 75, 823.

[100] Herring, A.C.; Falkowski, N.R.; Chen, G.H.; McDonald, R.A.; Toews, G.B.; Huffnagle, G.B. Infect. Immun. 2005, 73, 39.

[101] Mackay, A.; Ballin, M.; Pelina, M.; Farina, A.; Nason, A.; Hartzler, J.; Thorgeirsson, U. Invasion Metastasis 1992, 12, 168.

[102] Matsuyama, W.; Watanabe, M.; Shirahama, Y.; Oonakahara, K.; Higashimoto, I.; Yoshimura, T.; Osame, M.; Arimura, K. J. Immunol. 2005, 174, 6490 .

[103] Foda, H.D.; George, S.; Rollo, E.; Drews, M.; Conner, C.; Cao, J.; Panettieri, R.A.; Zucker, S. Am. J. Physiol. 1999, 277, L174.

[104] Louis, K.; Guerineau, N.; Fromigue, O.; Defamie, V.; Collazos, A.; Anglard, P.; Shipp, M.A.; Auberger, P.; Joubert, D.; Mari, B. J. Biol. Chem. 2005, 280, 1272.

[105] Mercer, B.A.; Kolesnikova, N.; Sonett, J.; D'Armiento, J. J. Biol. Chem. 2004, 279, 17690.

[106] Underwood, D.C.; Osborn, R.R.; Bochnowicz, S.; Webb, E.F.; Rieman, D.J.; Lee, J.C.; Romanic, A.M.; Adams, J.L.; Hay, D.W.; Griswold, D.E. Am. J. Physiol. Lung Cell Mol. Physiol. 2000, 279, L895.

[107] Lee, H.S.; Kim, H.J.; Moon, C.S.; Chong, Y.H.; Kang, J.L. Respir. Res. 2004, 5, 23 .

[108] Reunanen, N.; Westermarck, J.; Hakkinen, L.; Holmstrom, T.H.; Elo, I.; Eriksson, J.E.; Kahari, V.M. J. Biol. Chem. 1998, 273 5137

[109] Westermarck, J.; Holmstrom, T.; Ahonen, M.; Eriksson, J.E.; Kahari, V.M. Matrix Biol. 1998, 17, 547.

[110] Gum, R.; Wang, H.; Lengyel, E.; Juarez, J.; Boyd, D. Oncogene 1997, 14, 1481

[111] Saklatvala, J.; Dean, J.; Finch, A. Biochem. Soc. Symp. 1999, 64, 63.

[112] Kang, J.L.; Lee, H.W.; Lee, H.S.; Pack, I.S.; Castranova, V.; Koh, Y. Crit. Care Med. 2003, 31, 517.

[113] Demeule, M.; Brossard, M.; Page, M.; Gingras, D.; Beliveau, R. Biochim. Biophys. Acta 2000, 1478, 51.

[114] Shishodia, S.; Potdar, P.; Gairola, C.G.; Aggarwal, B.B Carcinogenesis 2003, 24, 1269.

[115] Sylvester, J.; Liacini, A.; Li, W.Q.; Dehnade, F.; Zafarullah, M. Mol. Pharmacol. 2001, 59, 1196.

[116] Lui, J. J. Ethnopharmacol. 1995, 49, 57.

[117] Mangelsdorf, D.J.; Thummel, C.; Beato, M.; Herrlich, P.; Schutz, G.; Umesono, K.; Blumberg, B.; Kastner, P.; Mark, M.; Chambon, P.; Evans, R.M. Cell 1995, 83, 835.

[118] Tuckermann, J.P.; Reichardt, H.M.; Arribas, R.; Richter, K.H.; Schutz, G.; Angel, P. J. Cell. Biol. 1999, 147, 1365.

[119] Eberhardt, W.; Schulze, M.; Engels, C.; Klasmeier, E.; Pfeilschifter, J. Mol. Endocrinol. 2002, 16, 1752.

[120] Um, S.J.; Han, H.S.; Kwon, Y.J.; Park, S.H.; Bae, T.S.; Rho, Y.S.; Sin, H.S. Oncol. Rep. 2004, 11, 719 .

[121] Brecher, A.R.; Orlow, S.J. J. Am. Acad. Dermatol. 2003, 49, 171.

[122] Blackhall, F.; Papakotoulas, P.I.; Danson, S.; Thatcher, N. Expert Opin. Pharmacother. 2005, 6, 1157 .

[123] Schoenermark, M.P.; Mitchell, T.I.; Rutter, J.L.; Reczek, P.R.; Brinckerhoff, C.E. Ann. N Y Acad. Sci. 1999, 878, 466.

[124] Luo, X.M.; Ross, A.C. J. Biol. Chem. 2005, 280, 36228.

[125] White, L.A.; Maute, C.; Brinckerhoff, C.E. Connect. Tissue Res. 1997, 36, 321.

[126] Trojanowska, M. Oncogene 2000, 19, 6464

[127] Bian, J.; Sun, Y. Mol. Cell Biol. 1997, 17, 6330.

[128] Wu, H.; Lozano, G. J. Biol. Chem. 1994, 269, 20067.

[129] Corbel, M.; Germain, N.; Lanchou, J.; Molet, S.; De Silva, P.M.; Martins, M.A.; Boichot, E.; Lagente, V. J Pharmacol Exp Ther. 2002, 301, 258.

[130] Massague, J.; Wotton, D. EMBO J. 2000, 19, 1745.

[131] Verrecchia, F.; Mauviel, A. J. Invest. Dermatol. 2002, 118, 211. 
[132] Yuan, W. Varga, J. J. Biol. Chem. 2001, 276, 38502.

[133] Bonniaud, P.; Kolb, M.; Galt, T.; Robertson, J.; Robbins, C.; Stampfli, M.; Lavery, C.; Margetts, P.J.; Roberts, A.B.; Gauldie, J. J. Immunol. 2004, 173, 2099.

[134] Uria, J.A.; Jimenez, M.G.; Balbin, M.; Freije, J.M.; Lopez-Otin, C. J. Biol. Chem. 1998, 273, 9769.

[135] Ricou, B.; Nicod, L.; Lacraz, S.; Welgus, H.G.; Suter, P.M.; Dayer, J-M. Am. J. Respir. Crit. Care Med. 1996, 154, 346.

[136] Hayashi, T.; Stetler-Stevenson, W.G.; Fleming, M.V.; Fishback, N.; Koss, M.N.; Liotta, L.A.; Ferrans, V.J.; Travis, W.D. Am. J. Pathol. 1996, 149, 1241.

[137] Madtes, D.K.; Elston, A.L.; Kaback, L.A.; Clark, J.G. Am. J. Respir. Cell Mol. Biol. 2001, 24, 599.
[138] Swiderski, R.E.; Dencoff, J.E.; Floerchinger, C.S.; Shapiro, S.D.; Hunninghake, G.W. Am. J. Pathol. 1998, 152, 821.

[139] Kim, K-H.; Burkhart, K.; Chen, P.; Frevert, C.W.; RandolphHabecker, J.; Hackman, R.C.; Soloway, P.D.; Madtes, D.K. Am. J. Respir. Cell Mol. Biol. 2005, 33, 271.

[140] Huang, Y.; Jiang, J.; Dou, K.; Chen, Z. Eur. J. Cell Biol. 2005, 84, 59 .

[141] Zhou, J.; Zhu, P.; Jiang, J.L.; Zhang, Q.; Wu, Z.B.; Yao, X.Y.; Tang, H.; Lu, N.; Yang, Y.; Chen, Z.N. BMC Cell Biol. 2005, 6 , 25.

[142] Menashi, S.; Serova, M.; Ma, L.; Vignot, S.; Mourah, S.; Calvo, F. Cancer Res. 2003, 63, 7575 .

[143] Taylor, P.M.; Woodfield R.J.; Hodgkin M.N.; Pettitt T.R.; Martin A.; Kerr D.J.; Wakelam M.J. Oncogene 2002, 21, 5765. 